\title{
Primerjava zagovora živali v Plutarhovi razpravi $O$ uživanju mesa in v Shelleyjevem Zagovoru naravne prehrane
}

\section{UVOD}

$\mathrm{V}$ pričujoči razpravi primerjam zagovor živali $\mathrm{v}$ dveh delih, ki promovirata rastlinsko prehrano; v dveh delih razprave De esu carnium, ki je del Plutarhovih Moralia, in v Shelleyjevem eseju A Vindication of Natural Diet (Zagovor naravne prehrane). Primerjava med deloma, med katerima je približno 1700 let razkoraka, je utemeljena na vplivu, ki ga je imelo Plutarhovo delo na nastanek Shelleyjevega besedila: Percy B. Shelley je bral Plutarhovo razpravo, ko je študiral na Univerzi v Oxfordu (pod vplivom razprave se je tedaj tudi pričel navduševati nad rastlinsko prehrano), in jo, kmalu zatem ko je zapustil Oxford, prevedel ter uporabil kot zgled ${ }^{1} \mathrm{za} \mathrm{Za}$ govor naravne prehrane, ki ga je dokončal jeseni 1812 in objavil kot pamflet leta $1813 .^{2}$

1 Clark, »Date and Source of Shelley's Vindication«, 72, navaja, da je Shelley pri pisanju Zagovora naravne prehrane (bolj ali manj kritično) uporabljal tudi druge vire; opozarja zlasti na vpliv Ritsonovega dela An Essay on the Abstinence from Animal Food iz leta 1802. Kot izhodišče za naslov je Shelley uporabil delo Mary Wollstonecraft $A$ Vindication of the Rights of Woman iz 1. 1792 (Morton, Shelley and Revolution in Taste, 69), eno najzgodnejših del buržoaznega feminizma, ki je utemeljeno na esencialistični predpostavki o ženski in z zagovorom razredne dominacije predstavlja pomembno oporo kapitalistični dominaciji.

2 Zagovor naravne prehrane je Shelleyjevo prvo prozno besedilo, v katerem postulira vegetarijanstvo. Dokončal ga je zgodaj novembra 1812 in ga vključil k Opombam h Queen Mab, ki je izšla 4 mesece kasneje (1813). Revidirano besedilo je leta 1813 (za Queen Mab) objavil kot samostojen esej. Sledili sta mu besedili A Refutation of Deism (1814) in On the Vegetable System of Diet (1815) (Clark, "Date and Source of Shelley's Vindication", 70-71; Morton, Shelley and Revolution in Taste, 65, 69 in 128). 
Raziskovalno pozornost sem usmerila zlasti na konceptualizacijo živali in obravnavo njihovega moralnega statusa v obeh besedilih ter na Shelleyjevo izpeljavo Plutarhove etične argumentacije, ob tem pa sem upoštevala družbeno-politični kontekst Shelleyjevega zagovora rastlinske prehrane. Pokazala bom, da Shelleyjevo besedilo kljub navideznemu zagovoru živali z vidika možnosti njihove subjektivizacije in preseganja strukturnih hierarhij v odnosu človek/žival ni radikalen diskurz, temveč utrjuje položaj živali kot podrejenih subjektov brez možnosti subjektivizacije.

\section{IZKLJUČITEV ŽIVALI IZ SFERE PRAVIČNOSTI PRI ARISTOTELU IN STOIŠKI KOZMOLOŠKI PRINCIP}

Antropocentrične koncepcije živali in njihovega moralnega statusa, ki so utemeljene na logiki, da za vsa človeška bitja in zgolj zanja veljajo načela moralne obravnave, ker imajo vsa človeška bitja in zgolj človeška bitja razum, jezikovno inteligenco in samozavedanje, imajo korenine pri Aristotelu in zlasti v stoiški misli. ${ }^{3}$ Epski pesniki in predsokratski misleci so prepoznavali svojstvenost človeških bitij, vendar pa razmerja človek/žival niso zastavili na metafizični ločnici; preobrat v pojmovanju razmerja človek/žival je nastopil z izrazito antropocentrično zastavitvijo razmejitvene črte med človekom in živaljo, temelječe na kognitivnih kapacitetah, kot sta razum in razumevanje. Ta preobrat pomeni začetek »antropocentrične krize «, ${ }_{4}^{4}$. razumevanja odnosa človek/žival v smislu nadpostavljenosti kognitivnih karakteristik in moralnega statusa človeških bitij. Kot prepričljivo trdi Richard Sorabji, »je prišlo do krize, ko je Aristotel živalim odrekel razum «.5

Aristotel omenja zmožnosti živali v dveh vrstah besedil: v zooloških tekstih, kot je npr. Zgodovina živali, in v psiholoških, metafizičnih in etično-političnih tekstih, zlasti v tekstih $O$ duši, Nikomahova etika in Politika. Čeprav Aristotel v zooloških tekstih živalim pripiše sposobnosti, kot so značaj, inteligenca, iznajdljivost in čustvene zmožnosti (ljubosumje, strah, pogum), pa jim v etično-političnih tekstih prav te zmožnosti odreče in jih obravnava kot izključno človeške. ${ }^{6}$ Najbolj očiten odklon od etično-političnih besedil je zaslediti v zooloških besedilih, v katerih Aristotel nekaterim živalim pripisuje jezikovne zmožnosti. V zooloških besedilih Aristotel razlikuje med živalmi, ki so sposobne proizvajati zvoke (npr. čebele), temi, ki so sposobne proizvajati glasove (med te uvršča živali z žrelom, npr. krave), in temi, ki so sposobne govora (tukaj misli na ptice, ki uporabljajo jezik kot sredstvo spo-

\footnotetext{
Steiner, Anthropocentrism and Its Discontents, 2.

Prav tam, 52.

Sorabji, Animal Minds and Human Morals, 7.

Steiner, Anthropocentrism and Its Discontents, 71-73.
} 
razumevanja $\mathrm{z}$ drugimi pticami). ${ }^{7} \mathrm{~V}$ Politiki pa vpelje razliko med glasom in govorom, kjer glas opredeli kot znamenje bolečine in ugodja, govoru pa pripiše funkcijo razkrivanja pravičnega in nepravičnega. Vsem živalim kategorično odreka sposobnost govora, češ da je govor izključna sposobnost racionalnih bitij; tj. bitij, ki so sposobna razlikovanja med pravičnim in krivičnim. ${ }^{8}$ S tem živali kategorično izključi iz etično-politične sfere. Gre za na videz nasprotna si, a dejansko komplementarna diskurza: v prvem diskurzu kaže pripravljenost priznati nekatere zmožnosti tudi živalim, v drugem delu, Politiki - in tu je pomenljivo prav to, da gre za njegovo ključno delo, tj. za filozofski traktat o ustroju družbe -, pa se obrne proti istim vzvodom teh zmožnosti in jih instrumentalizira za to, da legitimira hierarhično ureditev človeške družbe. Izključitev živali tako učinkuje kot argument za izključitev določenih skupin ljudi; razlika med človekom in živaljo se v človeški vrsti ponovi kot razlika med svobodnimi ljudmi in sužnji, kot razlika med moškimi in ženskami. ${ }^{9}$ Izključitev živali iz prostora političnega se torej "ponovno vpisuje $\mathrm{v}$ prostor političnega kot metafizična opora izključitvi določenega dela ljudi iz prostora političnega «. ${ }^{10}$ Razslojenost na temelju instrumentalizacije živali je relevantna za razumevanje današnjega ustroja demokracije, saj kaže na to, kako se umeščajo posamezne entitete znotraj družbenega reda, ki je deklariran kot demokracija - odprtost za etični govor je samo načelna, dopustna je pod pogojem, da ne vpliva na ustroj družbe; pojavlja se kot komplementaren diskurz vsakemu diskurzu, katerega podstat je sistematično in legalizirano izkoriščanje, saj nevtralizira jasen in transparenten naboj rasizma in hierarhizacije.

$\mathrm{S}$ tem ko Aristotel živalim odreče razum, naredi prvi odločilen korak $\mathrm{h}$ kategorični izključitvi živali iz sfere moralne obravnave. Stoiki pa z nadaljnjim omejevanjem pojma živalskih zmožnosti in z vključitvijo kozmološkega principa dokončno razvijejo antropocentrični vidik, po katerem so živali podrejene ljudem po kozmičnem redu. Kozmološki princip, po katerem ima vsako bitje točno določeno mesto v kozmični shemi, to mesto pa je določeno $\mathrm{s}$ kapacitetami bitja, predstavlja osnovo kozmopolitske etike, po kateri imajo v etičnem redu najvišje mesto tista bitja, ki so sposobna racionalnega premisleka. Tako je prvič v zgodovini zahodne filozofije človeški razum postavljen za osnovo moralni superiornosti človeških bitij nad živalmi. ${ }^{11}$ Moralna ločnica med človekom in živaljo je torej utemeljena na arbitrarnem kriteriju; Steiner ${ }^{12}$ poudarja, da je stoiški vidik motiviran s skrajnim antropocentrizmom, tj. z željo, prikazati človeška bitja kot edinstvena in središčna v kozmičnem redu

\footnotetext{
7 Prav tam, 74-75. Steiner opozarja na več mest v Aristotelovih zooloških besedilih, v katerih Aristotel izjavlja, da so pticam in ljudem skupne govorne kapacitete.

8 Aristotel, Politika 1.1253a 10-15.

9 Aristotel, Politika 1253b 1-8.

10 Komelj, „Este animal que soy«, 89.

11 Steiner, Anthropocentrism and Its Discontents, 77.

12 Steiner, Animals and the Moral Community, 137
} 
stvari. Logika, ki podpira kozmopolitski ideal, je namreč ta, da so zgolj racionalna bitja sposobna zavzeti univerzalno perspektivo in je zgolj iz te perspektive mogoče razumeti svet kot tak. Kanonična stoiška pozicija je, da so vsa tista bitja in zgolj tista bitja, ki so sposobna univerzalne perspektive, vključena v sfero pravičnosti; in ker živali nimajo mesta v skupnosti v višjem, kozmopolitskem smislu, ljudje v odnosu do živali ne moremo ravnati nepravično. ${ }^{13}$ Implikacija te pozicije je kategorično zanikanje dolžnosti pravičnosti do živali in skrajna implikacija zanikanje kakršnih koli neposrednih dolžnosti do živali: živali kot v temelju inferiorne racionalnim bitjem imajo v kozmičnem redu stvari zgolj instrumentalno vrednost in obstajajo zgolj za koristi racionalnih bitij. Iz kozmičnega principa torej sledi popolna izključitev živali iz sfere pravičnosti. Zgoraj navedeno Sorabjijevo trditev, da pomeni Aristotelovo odrekanje razuma živalim začetek antropocentrične krize, Gary Steiner nadgradi z mislijo, da "predstavlja stoiško zanikanje dolžnosti pravičnosti do živali vrhunec krize ${ }^{14}$

\section{PLUTARHOVA KRITIKA KANONIČNE STOIŠKE POZICIJE IN ZAGOVOR MORALNEGA STATUSA ŽIVALI}

Plutarh, ki ga Steiner imenuje »najbolj energičnega zagovornika kognitivnih sposobnosti živali med antičnimi misleci«, ${ }^{15}$ je v svojih besedilih o živalih odločno nastopil proti stoiškemu predsodku, da so vsa in zgolj človeška bitja člani sfere pravičnosti in da živali obstajajo zgolj za zadovoljevanje človeških želja. Kot poudarja Steiner, ${ }^{16}$ ta besedila predstavljajo prvo in najodločnejšo obrambo zmožnosti in moralnega statusa živali, ki je bila usmerjena proti stoiški poziciji. Glede na oblikovanje argumentacije o človekovih dolžnosti do živali lahko Plutarhova besedila o živalih razdelimo $\mathrm{v}$ dve obdobji, in sicer zgodnje, v katerem ultimativno zagovarja dolžnosti pravičnosti do živali (v to obdobje lahko uvrstimo vsa tri besedila, ohranjena v zbirki Moralia: Ali so pametnejše kopenske ali morske živali, Živali imajo razum, O uživanju mesa), in pozno obdobje, v katerem zagovarja dolžnosti sočutja do živali (v to obdobje sodi besedilo Življenje Marka Katona). Razprava, ki je bila predmet moje analize, O uživanju mesa, sodi v prvo obdobje in, kot ugotavlja že Steiner, ${ }^{17}$ vsebuje veliko, če ne vseh bistvenih elementov zagovora živali, ki predstavljajo temelj sodobnih razprav o moralnem statusu živali.

\footnotetext{
13 Prav tam, 134.

14 Steiner, Anthropocentrism and Its Discontents, 92.

15 Steiner, Animals and the Moral Community, 42.

16 Steiner, Anthropocentrism and Its Discontents, 103.

17 Prav tam, 94.
} 
Plutarh prične razpravo s tem, da problematizira samoumevnost prehranjevanja $\mathrm{z}$ mesom.

Ali me zares lahko sprašujete po razlogu, ki ga je imel Pitagora, da se je odrekel prehranjevanju z mesom? Kar se mene tiče, se raje sprašujem, po kakšnem naključju in v kakšnem stanju duše in telesa se je prvi človek, ki je to storil, s svojimi usti dotaknil zaklanega, si k ustom pomaknil meso mrtvega bitja, ta, ki je ljudem postregel s srhljivimi trupli in si drznil poimenovati meso in hrana dele, ki so še pred kratkim ljubili, jokali, se gibali in gledali. Kako je lahko prenesel pogled na pokol, ko so bili vratovi prerezani, kože odrte in okončine odtrgane? Kako je lahko prenesel ta smrad? Kako mu vsa ta grozota ni pokvarila okusa, medtem ko je žvečil rane drugih in okušal sokove smrtnih ran? /.../ Poiskati bi morali človeka, ki je s to prakso pričel, ne tega, ki jo je kasneje opustil. ${ }^{18}$

Navedeni citat je pomemben $\mathrm{z}$ vidika sodobnih diskurzivnih analiz reprezentacije živali, saj razkriva speciesistične ideološke predpostavke: Plutarh izpostavi samoumevnost poimenovanj "meso in hrana in tako na leksikalni ravni pokaže na izogibanje neposrednim poimenovanjem za dele ubitih živali in s tem na distanco do ubijanja živali. »Kot da ne bi nikoli obstajale kot misleča, čuteča posamezna bitja, ampak od vsega začetka zgolj kot kosi mesa - tako je jezikovno enačenje živih živali z deli njihovih trupel interpretirala analitičarka jezikovnega speciesizma Joan Dunayer. ${ }^{19}$ Kritika jezikovnih mehanizmov, s katerimi se vzpostavlja distanca do realnosti prehranjevanja z živalmi, je ena temeljnih prvin sodobnih kritičnih analiz vloge jezika pri institucionaliziranem zatiranju in izkoriščanju živali; zlasti teh, ki izpostavljajo simbolni pomen prehranjevanja $\mathrm{z}$ mesom; »simbolni pomen, ki je, « kot poudarja ekofeministka Carol Adams, »intrinzično patriarhalen in moškocentričen ${ }^{20}$ in kot tak utrjuje hierarhične binarne konstrukte. Meso postane simbol za to, kar ni vidno - kar je pomaknjeno v pozicijo drugosti.

Plutarh izhaja iz perspektive, da so izkustvene kapacitete živali dovolj bogate, da lahko uporabo živali za prehrano opredelimo kot očitno nepravičnost do živali. Zagovor rastlinske prehrane utemeljuje s tremi argumenti:

- duhovno-religioznim,

- antropološko-fizionomskim in

- etičnim.

Duhovno-religiozni in antropološko-fizionomski argument oblikujeta posreden, etični argument pa neposreden zagovor dolžnosti pravičnosti do

18 Plutarh, De esu carnium 993B.

19 Dunayer, Animal Equality, 139-140.

20 Adams, The Sexual Politics of Meat, 96. Adams pokaže na komplementarnost rasializacij, ki vzpostavljajo ženske in živalske subjekte kot podrejene. Tudi Plutarh, De esu carnium, na enem mestu poveže represijo nad živalmi z represijo nad ženskami: »Podobno se dogaja osebam, ki ne morejo obvladati nestrpnosti do žensk.» 
živali. Duhovno-religiozni argument je pri Plutarhu obstranskega pomena; utemeljen je na doktrini metempsihoze oz. preseljevanja duš, ${ }^{21}$ ki se Plutarhu sicer ne zdi povsem prepričljiva, vendar pa je mnenja, kot njegovo stališče do te doktrine povzame Steiner, ${ }^{22}$ da je iz previdnosti bolje biti nekoliko bolj konservativen.

Antropološko-fizionomski argument je zgrajen na ultimativni poziciji, da je prehranjevanje $\mathrm{z}$ mesom »tako nekoristno kot nepotrebno «. ${ }^{23}$ Plutarh poudarja, da »nasilnega prehranjevanja $\ll^{24}$ ni mogoče upravičiti, in med razlogi, da človek ubija živali za prehrano, navaja »lakomnost, objestnost in razkošje «, ${ }^{25}$ ki nizkotnost sprevračajo v užitek. Prakso prehranjevanja z mesom razume kot nedoumljivo krutost: »A ti, ki živiš zdaj, kakšna norost, kakšna blaznost te žene, da se skruniš s krvjo, ko pa ti je na voljo izobilje dobrin, potrebnih za preživetje? « ${ }^{26}$ Nenaravnost človekovega prehranjevanja z mesom dokazuje s komparativno anatomijo in zgradbo človekovega telesa. Poudari, da ljudje nimamo teles, primernih, da bi jedli meso; nimamo »ne ukrivljenega kljuna, ne ostrih krempljev, ne nazobčanih zob /.../ «; ${ }^{27}$ v nasprotju s karnivorimi živalmi, ki ubijejo in konzumirajo plen same, ljudje za ubijanje in razkosavanje živali potrebujemo pripomočke; »mesarski nož, gorjačo ali sekiro« ${ }^{28}$

Plutarh zavrne sklicevanje na zakone v naravi (tj. živali v naravi ubijajo druge živali) in s kritiko »naravnega reda stvari« prestopa iz sfere naravnega $\mathrm{v}$ sfero političnega. S postavljanjem razlike med plenilskimi živalmi, ki ubijajo »za preživetje «, ${ }^{29}$ in ljudmi, ki ubijajo za »za prigrizek «, ${ }^{\circ}$ izpostavi nujnost razlikovanja v koncepcijah plena: živali kot plena druge živali in človekovim pojmovanjem živali kot plena. Prav to razlikovanje pa zahteva racionalno refleksijo, iz katere izhaja moralna odgovornost. Plutarhova kritika »naravnega reda stvari« je zlasti aktualna v kontekstu danes prevladujočih ekoloških prizadevanj, ki oznanjajo načelo harmonije med živimi bitji kot apriorno »naravno ravnovesje« (deep ecology), saj zavrača misel, da bi bilo mogoče etične principe za živali izpeljati iz zakonov narave.

21 Nauk o metempsihozi je razvil Pitagora in se v zgodovini zahodne filozofije predstavlja z dveh vidikov. Prvi pogled na metempsihozo je, da imajo duše sposobnost, da se dvigujejo skozi različna utelešenja do popolne osvoboditve, $\mathrm{z}$ drugega vidika pa duše v neskončnost prehajajo iz enega utelešenja v drugo. Metempsihoza lahko vključuje tako človeška kot živalska telesa (duše imajo sposobnost prehajanja med človeškimi in živalskimi telesi) ali zgolj človeška telesa. Odnos do živali je pomemben v obeh primerih; če metempsihoza vključuje zgolj človeška telesa, je rastlinska prehrana pomembna za očiščenje duše, če pa vključuje tudi živalska telesa, je interes za rastlinsko prehrano in ustrezno ravnanje z živalmi še toliko večji, saj je po tem prepričanju mogoče pojesti sorodno dušo ali z njo slabo ravnati (Steiner, Anthropocentrism and Its Discontents, 45-46).

22 Steiner, Anthropocentrism and Its Discontents, 102.

23 Plutarh, De esu carnium 2, 999B.

24 Prav tam, 998C.

25 Prav tam, 997B.

26 Plutarh, De esu carnium 1, 994.

27 Prav tam, 995.

28 Prav tam, 995B.

29 Prav tam, 994B.

30 Pravtam. 
Oblast ljudi nad udomačenimi živalmi ima Plutarh za nelegitimno obliko dominacije. Pri tem moč nad živalmi pojmuje represivno in hierarhično: »Ne jemo levov in volkov /.../ ubijamo neškodljive in udomačene vrste, ki nimajo

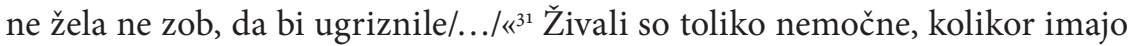
ljudje moči nad njimi. Plutarhovo razumevanje moči nad živalmi kot dominacije je zelo pomembno, saj kaže na razumevanje živalskega vprašanja kot političnega in s tem na vključitev živali v politično sfero.

Plutarh problematizira tako stoiško izključitev živali iz sfere pravičnosti kot antropocentrični argument za to izključitev; tj. razum kot merilo izključitve. V nasprotju s stoiki Plutarh trdi, da imajo živali inherentno vrednost, in na osnovi njihovih izkustvenih zmožnosti postavi ultimativno zahtevo po pravičnostnem odnosu med človeškimi bitji in živalmi. Plutarh zagovarja temeljni interes živali za življenje na osnovi priznavanja njihove perceptivne zavesti: »/Ž/ivo bitje /.../ ima določeno zaznavo, sluh, vid, domišlijo, inteligenco in vsakemu bitju so te sposobnosti naravno dane za zagotavljanje tega, kar je prijetno, in za izogibanje temu, kar je neprijetno. $\$^{32}$ To argumentacijo dosledno izpelje sodobni teoretik animalistične etike Gary Francione, ki zaznavno zavest postavi kot edino nujno kognitivno karakteristiko za enakopravno članstvo v moralni skupnosti:

Zavest je sredstvo za nadaljevanje eksistence. Zavedajoča se bitja, prav zato ker so zavedajoča se, imajo interes, da ostanejo živa. Reči torej, da zavedajočemu se bitju ne škodimo s smrtjo, zanikuje prav interes, ki se ohranja $z$ zavestjo. Analogno bi bilo reči, da bitje z očmi nima interesa za to, da bi še nadalje videlo, oz. mu ne škodimo, če ga oslepimo. ${ }^{33}$

Plutarh zagovarja moralno enakovrednost človeške in živalske zaznavne izkušnje in zagovor interesa živali, da ne trpijo, zavrne kot nezadosten. »Jaz pravim, da tisti, ki trpinči živo bitje, ni hujši od tega, ki ga na mestu umori.«34 Kljub temu, da zagovor inherentene vrednosti živalskega življenja pomeni preseganje antropocentrizma, pa se Plutarh te ideologije vendarle ne osvobodi povsem; vpelje namreč antropocentrično delitev na »divje« in uporabne živali; med slednjimi navaja »delovnega vola«, »ubogljivo ovco« in "petelina, ki pazi na hišo ${ }^{35}$ in s temi poimenovanji utrjuje antropocentrično predpostavko, ki vrednoti živali v smislu njihove uporabnosti za človeške namene. Uporaba živali je za Plutarha sprejemljiva, dokler je upoštevan interes živali, da živi.

Prav tako v Plutarhovem zagovoru moralnega statusa živali ni mogoče prezreti nekaterih antropomorfnih potez. $\mathrm{V}$ težnji, da bi spodkopal stoiški

31 Prav tam.

32 Plutarh, De esu carnium 2, $997 \mathrm{E}$.

33 Francione, »The Abolition of Animal Exploitation «, 15-16.

34 Plutarh, De esu carnium 1, 996B.

35 Plutarh, De esu carnium 2, 998B. 
predsodek, da so živali fundamentalno neracionalne in posledično podrejene ljudem, Plutarh ponudi vrsto dokazov o njihovih kognitivnih sposobnostih. ${ }^{36}$ Pripoznava zaznavno izkušnjo živali, vendar pa pri pojmovanju živalskega vedenja izhaja iz analogije z lastno (tj. človeško) izkušnjo; posledica tega je antropomorfizacija živalske izkušnje. Tako denimo živalim pripiše moledovanje, rotenje, obsojanje: »Kot bi nam govorile: 'Ne prosim te, da mi prizaneseš, če gre za potrebo; a prizanesi mi z aroganco! Ubij me za prehrano, a ne vzemi mi življenja za priboljšek!'«37

Kljub Plutarhovi ultimativni pravičnostni poziciji v razmerju človek/žival v njegovem zgodnjem obdobju pa se v Plutarhovem pogledu na moralni status živali v njegovem poznem obdobju zgodi zasuk, ki ga ni mogoče pojasniti: korenit preobrat od etike, osnovane na pravičnosti, k etiki, osnovani na sočutju. Sočutje Plutarh opredeli s širšim razponom kot pravičnost in pravičnost prične aplicirati izključno na ljudi. ${ }^{38}$ Če lahko pri zgodnjem Plutarhu prepoznamo zahtevo po pravičnostnem odnosu kot konstitutivni element zagovorništva pravic živali, ${ }^{39}$ pa je pozni Plutarh zgodnji zagovornik zaščite živali, ${ }^{40} \mathrm{ki}$ je utemeljena na hierarhičnem razvrščanju vrednosti človeškega in živalskega življenja ter na zagovoru dolžnosti sočutja do živali. Dolžnost sočutja pomeni dolžnost identifikacije z njihovim trpljenjem, ta dolžnost pa ne zahteva spremembe $\mathrm{v}$ našem moralnem vedenju, tj. ne zahteva kategorične odpovedi uporabi in ubijanju živali za lastne namene. Abolicionistična kritika ${ }^{41}$ zaščitniškega pristopa si prizadeva pokazati, da so dolžnosti sočutja neustrezne za priznanje moralnega spoštovanja, ki ga dolgujemo živalim.

Kljub temu preobratu pa etična argumentacija iz Plutarhovega zgodnjega obdobja glede vprašanja pravičnosti do živali ostaja prepričljiva tudi v sodobnih razpravah s področja animalistične etike.

36 Steiner, Anthropocentrism and Its Discontents, 97, opozarja, da je v prizadevanju za prikazovanje podobnosti živalske izkušnje s človeško nevarnost antropomorfizacije neizogibna.

37 Plutarh, De esu carnium 1, 994E.

38 Steiner, Animals and the Moral Community, 120. Steiner tudi navaja, da je Plutarh sočasno s preobratom v vprašanju pravičnosti do živali opustil tudi vegetarijansko prehrano.

39 Teorija pravic živali, ki jo je razvil Gary L. Francione sredi devetdesetih let 20. stol. (Animals, Property and the Law; Rain Without Thunder idr.), je utemeljena na načelu enakovredne obravnave, ki za živali zahteva enakopravno članstvo v moralni skupnosti in posledično moralno enakovrednost človeškega in živalskega življenja, ter si prizadeva za odpravo lastninskega statusa živali kot osnovo za popolno odpravo izkoriščanja živali in njihove uporabe za človeške namene.

40 Začetki zaščitniške animalistične teorije segajo v 19. stol. in so artikulirani v vprašanju utilitarističnega filozofa Jeremyja Benthama: »/V/prašanje ni, Ali lahko razmišljajo?, tudi ne, Ali lahko govorijo?, temveč, Ali lahko trpijo? « (Bentham, Introduction to Principles of Morals, 310-311.) $\mathrm{V}$ primerjavi z Benthamom vodilni predstavnik sodobne zaščitniške animalistične teorije Peter Singer, Animal Liberation, eksplicitno opredeli moralno večvrednost človeškega življenja.

41 Npr. Francione, Introduction to Animal Rights; Animals as Persons; "The Abolition of Animal Exploitation«; Steiner, Animals and the Moral Community. 


\section{KAKO JE SHELLEY IZ PLUTARHOVEGA ZAGOVORA ŽIVALI IZPELJAL ŽIVLJENJSKI SLOG Z NASTAVKI LIBERALNEGA INDIVIDUALIZMA}

Shelley v Zagovoru naravne prehrane Plutarhov etični argument pravičnosti iz razprave $O$ uživanju mesa v celoti nadomesti s t. i. »lifestyle« argumentom, tj. Plutarhov značilni govor o človekovih moralnih dolžnostih do živali nadomesti $z$ retoriko čistosti, nepokvarjenosti »fizične in moralne narave človeka« ${ }^{42}$ Liberalni obrat k retoriki skrbi za zdravo življenje preglasi vsakršno pravičnostno skrb za enakovredno moralno obravnavo človeka in živali: „Če bomo sledili naravni prehrani, bo starost naša zadnja in edina tegoba.«43 Vprašanje »Kako se lahko prednosti intelekta in civilizacije uskladijo s svobodo in čistim užitkom naravnega življenja? «4 (izpostavila B. V.) kaže na sprevračanje in preosmišljenje Plutarhovega zagovora živali in neposredno podpira končno izpeljavo liberalnega individuuma, ki se vzpostavlja $v$ razmerju do življenjskega sloga kot samozadostne politike. Shelley svoje argumentacije ne izgrajuje s koncepcijo pravičnosti kot Plutarh, temveč s koncepcijami sreče, zadovoljstva in užitka posameznika. Tako je etična teorija v 19. stol. »V prizadevanju za ponotranjenost dobrega življenja izgubila nujni element dolžnosti in moralne sodbe«. 45

Uvodni del eseja Shelley izgradi z interpretacijo biblične zgodbe o Ada$\mathrm{mu}$ in Evi in mita o Prometeju. Motiva sta pogosto vključena v romantični zagovor vegetarijanske prehrane; najdemo ju npr. pri Josephu Ritsonu (1802) ${ }^{46}$ Johnu Franku Newtonu (1811), ${ }^{47}$ kasneje (1818) pa na njuni osnovi Mary Shelley oblikuje Frankensteina. Po Shelleyjevi romantični vegetarijanski interpretaciji mit o Prometeju razlaga izvor človekovega prehranjevanja $\mathrm{z}$ mesom; meso mora biti kuhano, da je užitno: "Prometej (ki predstavlja človeško vrsto) je zelo spremenil svojo naravo in uporabil ogenj za kulinarične namene. ${ }^{48}{ }^{4}$ Kaznovanje $\mathrm{z}$ jastrebom, ki je Prometeju vsak dan izkljuval jetra, Shelley interpretira kot kazen za uporabo ognja, da se z njim prikrijejo "grozote klavnice ${ }^{49}$ Morton razlaga Shelleyjevo interpretacijo mita v smislu kritike akulturacije: »kuhanje spreminja neobdelano naravo v kulturo «.5०

Pretežen del razprav o Shelleyjevih besedilih o vegetarijanstvu Shelleyjevo retoriko razume kot družbeno konstitutivno in ji pripisuje politične konsekvence, ${ }^{51}$ vendar se s tem ni mogoče strinjati, v kolikor politično (v raz-

42 Shelley, A Vindication of Natural Diet, 9.

43 Prav tam, 18.

44 Prav tam, 12.

45 Bredvold, The Natural History of Sensibility, 100.

46 Ritson, Essay on Abstinence from Animal Food.

47 Newton, The Return to Nature.

48 Shelley, A Vindication of Natural Diet, 11.

49 Prav tam.

50 Morton, Shelley and Revolution in Taste, 47.

51 Npr. Morton, Shelley and Revolution in Taste; Adams, The Sexual Politics of Meat idr. 
merju človek/žival) razumemo v smislu preseganja strukturnih hierarhij. Z vidika moralnega statusa živali Shelleyjev Zagovor naravne prehrane ne izraža zahteve po enakovredni moralni obravnavi, kot navaja Adams, ${ }^{52}$ ampak vpeljuje zagovor avto- in heteroreferenčnega speciesizma. ${ }^{53}$ Avtoreferenčni speciesizem se kaže v koceptualizaciji človeka kot superiorne biološke vrste; konstitutivna prvina Shelleyjeve argumentacije niso človekove moralne dolžnosti do živali, ampak »doprinos za človeško vrsto«.54 Shelley oblikuje hierarhijo, kjer je človek tisti, ki zavzame prednostno pozicijo: »Kako lahko izkoristimo prednosti in se zavarujemo pred slabostmi organizma, ki je prepleten z vsemi vlakni naše biti? Verjamem, da bi nas opustitev živalske hrane in žganih pijač v veliki meri usposobila za razrešitev tega pomembnega vprašanja. «55 Par živalska hrana - žgane pijače, ki se v besedilu pojavlja s protipomensko dvojico rastlinska prehrana - čista voda, je eno od izrazil heteroreferenčne oblike speciesizma, tj. oblike speciesizma, ki pozicionira živali kot podrejeno oz. oporečno, nevarno vrsto; živali so konceptualizirane $\mathrm{z}$ vidika učinkovanja na človeka in moralno izenačene $\mathrm{z}$ alkoholom kot opojno substanco. $\mathrm{V}$ privzeti retoriki zdravja in bolezni, značilni za romantično obdobje, so živali označene kot vrsta, ki nosi v sebi kal bolezni. Iz izrekov (1) »Zločin je norost« in (2) »Norost je bolezen «" ${ }^{56}$ sledi: (3) Zločin (nad živaljo) je bolezen. V tej argumentaciji je žival ožigosana kot »vzrok bolezni «, ${ }^{77} \mathrm{tj}$. objektivizirana kot nekaj, kar povzroča razbolevanje, razpad organizma. Zastrupljanje človeškega organizma $\mathrm{z}$ mesom živali, ${ }^{58}$ tj. zastrupljanje človeške vrste, Shelley opredeli kot »izvirni in univerzalni greh «.59 Tako oblikuje živalsko vrsto kot imaginarno skupnost, ki je obravnavana in posledično pojmovana kot kontaminirajoča, oporečna oz. nevarna za človeško vrsto. S tem označevanjem, ki deluje kot sredstvo izključevanja oz. marginalizacije, živali diskurzivno postavlja za nižjo obliko življenja. Žival je - ne glede na to, ali je inkorporirana v organizem ali stoji zunaj njega - postavljena v inferiorno pozicijo bolezni. S takim pozicioniranjem Shelley utrjuje inferiorno pozicijo živali kot drugega. ${ }^{60}$

52 Adams, The Sexual Politics of Meat, 124.

53 Razlikovanje med avtoreferenčni in heteroreferenčnim speciesizmom (tj. ideologije superiornosti človeške vrste nad drugimi biološkimi vrstami) vpeljujem po analogiji z avto- in heteroreferenčnim rasizmom po Balibar, "Racism and Nationalism», 39. Prvo obliko označujejo nasilne in simbolne oblike nasilja, ki postavljajo nosilce predsodkov za superiorno raso; druga postavlja žrtve rasizma oz. procesa rasializacije za inferiorno oz. problematično, nevarno raso. O kulturnem rasizmu v evro-atlantskih demokracijah prim. Burcar, "Multikulturalizem in diskurz tolerance".

54 Shelley, A Vindication of Natural Diet, 16.

55 Prav tam, 12.

56 Glej op. 54. Shelley je ta del povzel iz Ritsona (Clark, »Date and Source of Shelley's Vindication«, 74).

57 Shelley, A Vindication of Natural Diet, 16.

58 Prav tam, 20.

59 Prav tam, 18.

60 Označevanje določenih skupnosti kot potencialno bolnih (hierarhiziranje populacije na zdrave/ bolne) je v 19. stol. vgrajeno v konstitucijo nacije. Za skupine ljudi, ki veljajo za bolne, postane ta 
Shelley je Zagovor naravne prehrane namenil vladajočemu aristokratsko-buržoaznemu razredu, saj, kot navaja, »lahko zgolj bogati do popolnosti, celo zdaj, zadovoljijo nenaravno potrebo po mrtvem mesu . $^{61}$ Esej zaključi v preskriptivnem registru (sprememba registra je tudi oblikovno poantirana):

"NIKOLI NE ZAUŽIJTE NOBENE SUBSTANCE, KI JE IMELA ŽIVLJENJE.

NE PIJTE DRUGIH TEKOČIN KOT VODO, KI JI JE BILA POVRNJENA PRVOTNA ČISTOST Z DESTILACIJO. ${ }^{62}$

Ekonomsko-politični položaj delavskega razreda v obdobju kapitalistične industrializacije je delavstvu povsem onemogočal pogoje dolgega in zdravega življenja, ki ga Shelley na več mestih poudarja kot učinek reforme življenjskega sloga. Medtem ko je vladajoči razred $» z$ zdravjem plačeval za razkošno življenje,$^{63}$ je bilo na tisoče predstavnikov delavskega razreda prikrajšanih za najosnovnejša sredstva za golo preživetje..$^{64} »$ Kako bi mogel nižji razred pod takimi pogoji imeti zdravo in dolgo življenje? Kaj drugega je moč pričakovati kot prekomerno umrljivost, ponavljajoče se epidemije in telesni propad delavske populacije? « povzame položaj angleškega delavstva v prvi polovici 19. stol. Engels. ${ }^{65}$ Vendar pa Shelley izvora sistemskih potez, kot so razredna izključevanja, ne pripiše kapitalizmu, temveč prehranjevanju z mesom. Poziv aristokratsko-buržoaznemu razredu, naj opusti prehranjevanje z mesom, predstavi kot možnost za odpravo neenakosti v družbeno-političnih razmerjih: »Prednost spremembe v prehrani je večja od katere koli druge. Zadene v samo bistvo zla. «66 Tako okrnjenega pogleda na družbeni svet, kapitalistično ekonomijo in ekspanzijsko politiko tudi ne moremo brati kot politično potezo, ki bi vodila k preseganju razrednih hierarhij. S tem ko se Shelley osredinja na življenjski slog, ne na pravičnost, tudi ohranja metode, ki ne morejo preseči kapitalističnega okvira. Shelley na ta način dejanske vzroke eksploatacijskih praks odtujuje, odmika in potiska v ozadje, njegova argumentacija pa pod oznako etičnosti deluje kot posebna oblika sedativa, tj. zamegljevanja dejanskosti in služi ohranjanju položaja vladajočega razreda, ki mu je

oznaka del identitetne oznake. »/P/odoba 'bolnega Juda' kot del skupnosti bolnih« (Gilman, Jewish Frontiers, 163) je, podprta z znanstvenim antisemitizmom (Gilman, »Sibling Incest«, 403), del kolektivnega imaginarija 19. stol. in je v 20. stol. oživljena kot sestavni del reprezentacije »ekonomskega' problema prisotnosti Judov v moderni družbi« (Gilman, »Sibling Incest«, 408).

61 Shelley, A Vindication of Natural Diet, 21.

62 Prav tam, 26.

63 Glej op. 61.

64 Tudi pitje alkohola (Shelley njegove škodljive posledice izpostavlja na več mestih) ima pri vladajočem razredu povsem druge vzvode kot pri deprivilegiranem, delavskem razredu: povečana izpostavljenost delavskega razreda alkoholu je bila neposredno povezana s kapitalistično eksploatacijo delavstva (Engels, Condition of Working-Class in England).

65 Engels, Condition of Working-Class in England, 98.

66 Shelley, A Vindication of Natural Diet, 23. 
Shelley tudi sam pripadal. Ali kot liberalistični vidik metaforično prikaže Fleming: ${ }^{67}$

Liberalci skušajo razkleniti spone določenih okoliščin in tradicij in si pri tem prizadevajo zavzeti dolgoročen pogled na človeško življenje in njegove možnosti; a ko usmerjajo pogled k popolnemu sončnemu zahodu pod nenehno oddaljujočim se obzorjem, je precej verjetno, da bodo spregledali majhne stvari, ki jih lahko imajo tik pred nosom. Tak moralni in politični idealizem lahko proizvaja briljantne utopične teorije $/ . .{ }^{68}$

\section{BIBLIOGRAFIJA}

Adams, Carol. The Sexual Politics of Meat: A Feminist-vegetarian Critical Theory. 10. izd. New York: Continuum International Publishing Group, 2000.

Aristotel, Politika. Prevod Matej Hriberšek. Ljubljana: GV Založba, 2010.

Balibar, Etienne. "Racism and Nationalism.« V: Race, Nation, Class: Ambiguous Identities, Etienne Balibar, Immanuel Wallerstein, 37-67. London, New York: Verso, 1991.

Bentham, Jeremy. An Introduction to the Principles of Morals and Legislation. New York: Hafner, 1948.

Burcar, Lilijana. »Multikulturalizem in diskurz tolerance v dobi globalnega kapitalizma in neorasizma«. Šolsko polje XXI, št. 5-6 (2010): 151-180.

Bredvold, Louis I. The Natural History of Sensibility. Michigan: Wayne State University Press, 1962.

Clark, David Lee. »The Date and Source of Shelley's 'A Vindication of Natural Diet'«. Studies in Philology 36.1 (1939): 70-76.

Dunayer, Joan. Animal Equality: Language and Liberation. Derwood: Ryce Publishing, 2001.

Engels, Frederick. The Condition of the Working-Class in England in 1844. Prevod Florence Kelley Wischnewetzky. New York: J. W. Lovell, 1887.

Fleming, Thomas. Morality of Everyday Life: Rediscovering an Ancient Alternative to the Liberal Tradition. Missouri: University of Missouri Press, 2004.

Francione, Gary L. Animals, Property and the Law. Philadelphia: Temple University Press, 1995.

. Animals As Persons: Essays on the Abolition of Animal Exploitation. New York: Columbia University Press, 2008.

67 Fleming, Morality of Everyday Life, 7.

68 Danes je npr. opazen pojav kooptacije veganstva, ki jo podpirajo številna (neo)utilitaristična živalovarstvena gibanja. Če veganstvo kot politično gibanje proti sistemu izkoriščanja prenastavimo in preosmislimo kot potrošniški življenjski slog (kjer je zahodni slog življenja evfemizem za to, da eni druge zatirajo), postane sestavni del kapitalističnega sistema; tj. postane podporna oblika mednarodne delitve dela, kakor jo usmerjajo kapitalistične države. Politično neozaveščeno rastlinsko prehranjevanje se s konzumacijo in promocijo izdelkov, ki so v okviru globalnega kapitalizma povezani s prizorišči množičnega izkoriščanja, vključuje v širšo sliko kapitalistične ekonomije (npr. neokolonialne plantaže palm v Indoneziji za proizvodnjo palmovega olja, ki služi potrebam trga, ki ga na mednarodni ravni oblikujejo imperialistične velesile). 
Introduction to Animal Rights: Your Child or the Dog? Philadelphia: Temple University Press, 2000.

- Rain without Thunder: The Ideology of the Animal Rights Movement. Philadelphia: Temple University Press, 1996.

—. »The Abolition of Animal Exploitation«. V: The Animal Rights Debate, Gary L. Francione, Robert Garner, 1-102. New York: Columbia University Press, 2010.

Gilman, Sander L. »Sibling Incest, Madness, and the 'Jews'«. Social Research 65, št. 2 (1998): 401-433.

. Jewish Frontiers: Essays on Bodies, Histories, and Identities. New York: Palgrave Macmillan, 2003.

Komelj, Miklavž. »Este animal que soy.« V: Nujnost poezije, Miklavž Komelj, 53-117. Koper: Hyperion, 2010.

Morton, Timothy. Shelley and Revolution in Taste: The Body and the Natural World. New York: Cambridge University Press, 1994.

Newton, John Frank. The Return to Nature: or, A Defence of the Vegetable Regimen. Cadell and Davies, 1911.

Plutarh. Plutarch's Moralia: In Fifteen Volumes. 12. zvezek. Prevod Harold Cherniss in W. C Helmbold. London / Cambridge, Mass.: W. Heinemann / Harvard University Press, 1968.

Ritson, Joseph. An Essay on Abstinence from Animal Food, as a Moral Duty. London: Richard Phillips, 1802.

Singer, Peter. Animal Liberation. 2. izd. New York: New York Review of Books, 1990.

Shelley, Percy Bysshe. A Vindication of Natural Diet. London: F. Pitman, Manchester: J. Heywood, 1884.

Sorabji, Richard. Animal Minds and Human Morals: The Origins of the Western Debate. New York: Cornell University Press, 1993.

Steiner, Gary. Anthropocentrism and Its Discontents: The Moral Status of Animals in the History of Western Philosophy. Pittsburg: University of Pittsburg Press, 2005.

- Animals and the Moral Community: Mental Life, Moral Status, and Kinship. New York: Columbia University Press, 2008.

Vičar, Branislava. »Moralna vrednost živali v diskurzu biotske raznovrstnosti«. V: Meddisciplinarnost $v$ slovenistiki, ur. Simona Kranjc, 509-514. Ljubljana: Znanstvena založba Filozofske fakultete, 2011. 


\section{COMPARISON OF PLUTARCH'S DEFENCE OF ANIMALS IN THE TREATISE ON THE EATING OF FLESH AND SHELLEY'S A VINDICATION OF NATURAL DIET}

\section{Summary}

The paper compares the defence of animals in two texts which promote a vegetable diet: in Plutarch's essay from Moralia, On the Eating of Flesh, and Shelley's essay A Vindication of Natural Diet. The paper focuses on the conceptualisation of animals and consideration of their moral status in both texts and on Shelley's treatment of Plutarch's ethical argument.

Anthropocentric conceptions of animals and their moral status, based on the logic that all and only human beings deserve to be treated on the principles of moral consideration because all and only human beings possess reason, linguistic intelligence and self-awareness, have their roots in Aristotle and in particular in Stoic thought. The canonical Stoic position is based on the cosmological principle, by which each being has a specific place in the scheme of the cosmos, whereby this proper place is determined by the capacities of the being; the highest place belongs to those beings who are capable of rational contemplation. The implication of this position is the categorical denial of the duty of justice toward animals, and the ultimate implication is the denial of any direct duties toward animals: animals as fundamentally inferior to rational beings have only instrumental value in the cosmic scheme of things and exist only for the benefit of rational beings. Plutarch's texts on animals in his early work (Whether Land or Sea Animals Are Cleverer, Beasts Are Rational, On the Eating of Flesh) represent the first and most spirited defence of the capacities and moral status of animals, directed against the Stoic position. In contrast to the Stoics, Plutarch argues that animals have inherent value, and ultimately calls for a justice relationship between human beings and animals on the basis of their experiental capacities. Plutarch defends the view that animals have a fundamental interest to live on the basis of recognising animal perceptual awareness. He advocates the moral equality of human and animal sentient experience and rejects the view that animals' fundamental interest is not to suffer as inadequate.

The essay A Vindication of Natural Diet by Percy B. Shelley, while primarily based on Plutarch's treatise, comes to conclusions supporting the lifestyle argument with emerging elements of liberal individualism. Shelley's argumentation is not built on the conception of justice like Plutarch's, but on the conceptions of happiness, satisfaction and enjoyment of the individual. Plutarch's ethical argument is replaced by the so-called 'lifestyle' argument, which is completely in accordance with the self-centred and self-oriented Romantic as a self-sufficient subject in the early $19^{\text {th }}$ century. In terms of con- 
sideration of animals and their moral status, it is particularly important that Shelley in this essay does not actually argue for animals, but rather for speciesism, that is, he builds his argumentation on the hierarchisation in which humans hold the top position. 